\title{
Maturation-Related Changes in Dopamine- Induced Relaxation of Isolated Rabbit Pulmonary Artery
}

\author{
MIYAKO MORI, YUKO HOSHINO, HIDEFUMI OBARA, AND SEIZO IWAI \\ Department of Anesthesiology, Kobe University School of Medicine, Kusunoki-cho-7, Chuo-ku, Kobe, 650 Japan
}

\begin{abstract}
Studies were performed on isolated pulmonary arterial segments to investigate dopamine receptormediated relaxant effects at different times during development. Dopamine receptor-mediated relaxant effects can only be observed when vessels are precontracted with prostaglandin $F_{2 \alpha}$ and in the presence of $\alpha_{1}, \alpha_{2}, \beta$, and serotonergic blockade. Helical strips of pulmonary arteries from rabbits of different ages $(2,7,14,30$, and 90 days), partially precontracted by prostaglandin $F_{2 \alpha}$ were tested for their responses to dopamine in the presence of prazosin $\left(10^{-6} \mathrm{M}\right)$, yohimbin $\left(10^{-6} \mathrm{M}\right)$, propranolol $\left(10^{-6} \mathrm{M}\right)$, and methysergide $\left(10^{-6} \mathrm{M}\right)$. Strips from 2- and 7-day-old rabbits were not induced to relax by dopamine, whereas those from 14-, 30-, and 90-day-old animals, after cumulative application of dopamine, underwent concentration-dependent relaxation. Dopamine (half the maximum response) concentration decreased during the development of rabbits from 14 to 90 days old. Mean values for apparent dopamine ED50 (half the maximum response) concentrations in the arteries of 14-, 30-, and 90-day old animals were $4.94 \pm$ $0.40,2.02 \pm 0.30$, and $0.113 \pm 0.028 \mu \mathrm{M}$, respectively. The effects of various dopamine antagonists on dopamineinduced relaxation were not markedly different at different ages. These findings indicate that dopamine receptor function is not fully developed in the pulmonary arteries of newborn rabbits, but matures as the age of the rabbit increases. (Pediatr Res 24: 160-165, 1988)
\end{abstract}

\section{Abbreviations}

ED50 concentration, concentration that produced half the maximum response

$\mathbf{p A}_{2}$ value, the negative logarithm of the molar concentration of the antagonist that produces a 2 -fold shift to the right of the dose-response curve for the agonist

Dopamine stimulates $\beta_{1}$-adrenergic receptors causing positive inotropy and has been used to treat shock and congestive heart failure. In high doses, it also stimulates $\alpha_{1}$-adrenergic receptors causing vasoconstriction. In low doses, however, specific dopaminergic receptors mediate vasodilation.

In the cardiovascular system specific dopaminergic receptors are found in renal, mesenteric, splenic, coronary, cerebral, and femoral arteries. A vascular dopaminergic receptor classification has been proposed by Goldberg and Kohli $(1,2)$, in which the $\mathrm{DA}_{1}$ receptor subserves smooth muscle relaxation, and the $\mathrm{DA}_{2}$

Received December 29, 1987; accepted March 18, 1988

Correspondence Dr. Miyako Mori, Department of Anesthesiology, Kobe University School of Medicine, Kusunoki-cho-7, Chuo-ku, Kobe, 650 Japan.

Supported by grants from the Ministry of Education, Japan. receptor subserves the inhibition of noradrenaline release from postganglionic sympathetic nerves. Previously, we confirmed the existence of $\mathrm{DA}_{1}$ dopamine receptors in the adult rabbit pulmonary artery (3). Dopamine produced a concentration-dependent relaxation of arterial strips contracted with prostaglandin $F_{2 \alpha}$ in the presence of prazosin ( $\alpha_{1}$-blocker), yohimbin $\left(\alpha_{2}\right.$-blocker $)$, propranolol ( $\beta$-blocker), and methysergide (serotonin-blocker).

The pulmonary circulatory system undergoes considerable anatomic and physiologic remodeling during early neonatal life. Furthermore, it is widely accepted that responses of vascular smooth muscles, including that of the pulmonary artery, differ in animals of different ages. For instance, responses to vasodilators that operate through $\beta$-adrenergic receptors have been shown to increase early in development $(4,5)$. Dopamine, therefore, may affect the pulmonary circulation of newborns and infants in a way different from that of adults. However, agerelated changes to dopamine response in isolated pulmonary arteries have not previously been reported.

Thus, we compared the responses to dopamine at different times during development in isolated rabbit pulmonary arteries. We also examined the characteristics of dopamine receptors.

\section{MATERIALS AND METHODS}

Animals. Rabbits of either sex in five different age groups were used. The 2-day-old group consisted of rabbits 1-3 days of age; the 7-day-old group consisted of rabbits 5-9 days of age; the 14day-old group consisted of rabbits 12-17 days of age; the 30-dayold group consisted of rabbits 27-34 days of age; and the adult group (90-day-old group) consisted of animals between $80-110$ days of age. The numbers of animals used were $8,7,30,30$, and 30 for the 2-, 7-, 14-, 30-, and 90-day-old groups, respectively. No more than three rabbits from a litter were used in a given group and there was no variance between litters at a given gestational age. All animals were killed by bleeding the carotid arteries after administration of $30 \mathrm{mg} / \mathrm{kg}$ sodium pentobarbital either intraperitoneally into the 2-, 7-, 14-, and 30-day-old animals or intravenously into the adult animals.

Vessel preparation. Pulmonary arteries were removed from each animal and immediately placed in Krebs-Ringer solution of the following composition: $118 \mathrm{mM} \mathrm{NaCl}, 4.8 \mathrm{mM} \mathrm{KCl}, 2.5$ $\mathrm{mM} \mathrm{CaCl}_{2}, 25.0 \mathrm{mM} \mathrm{NaHCO}, 1.18 \mathrm{mM} \mathrm{KH}{ }_{2} \mathrm{PO}_{4}, 1.19 \mathrm{mM}$ $\mathrm{MgSO}_{4}$, and $11 \mathrm{mM}$ glucose. After being cleaned of adhering fat and connective tissue, the isolated arteries were cut into helical strips approximately $1.5-\mathrm{mm}$ wide and $15-\mathrm{mm}$ long. The helical strips were suspended in a $20 \mathrm{ml}$ tissue bath containing KrebsRinger solution at $37^{\circ} \mathrm{C}$, through which $95 \% \mathrm{O}_{2} / 5 \% \mathrm{CO}_{2}$ was continuously bubbled. The strips were maintained under an optimal resting tension (Table 1). The optimal resting tension was defined as that precontraction tension that allowed maximal isometric contraction to occur after the addition of $30 \mathrm{mM} \mathrm{KCl}$ (6) as determined in a pilot study. The cross-sectional areas of 
the strips were estimated from the wet weight/length at the resting tension, a calculation that assumed a tissue density of $1(7,8)$ (Table 1).

The strips were mounted between a fixed base and an isometrical transducer (Nihon Koden TB 612-T) which allowed the contraction to be registered on a polygraph (SAN-EI 141-6). Before exposing the strips to any test drug, all tissues were equilibrated for $90 \mathrm{~min}$, during which time the bathing medium was replaced every $15 \mathrm{~min}$. Maximum contraction was then induced by $30 \mathrm{mM} \mathrm{KCl}$, after which the preparations were repeatedly washed and reequilibrated in control media. Next, to determine the concentration of prostaglandin $F_{2 \alpha}$ required to induce approximately $80 \%$ maximal contraction, dose response curves for the drug were obtained.

Maturation-related change in response to dopamine. Alpha ${ }_{1}^{-}$, $\alpha_{2^{-}}, \beta$-adrenergic, and serotonergic receptor blockades were achieved by the addition of prazosin $(1 \mu \mathrm{M})$, yohimbin $(1 \mu \mathrm{M})$, propranolol $(1 \mu \mathrm{M})$, and methysergide $(1 \mu \mathrm{M})$, respectively, to the medium. These blockers were used to eliminate any effects of dopamine mediated through these receptors. Among these blockers, prazosin is important in the detection of dopamineinduced relaxation since $\alpha_{1}$ constriction can overshadow the response. The $\mathrm{pA}_{2}$ value of prazosin is approximately 8.2 when norepinephrine is chosen as an agonist. Thus $10 \mu \mathrm{M}$ prazosin is adequate $(9,10)$. In some experiments for the 2-, 7-, and 14-dayold groups, higher concentrations (5 and $10 \mu \mathrm{M})$ of prazosin were used to examine if the decreased sensitivity to dopamine in younger rabbits was due to a counteractive effect on $\alpha$-receptors. After $20 \mathrm{~min}$, pulmonary arterial strips were contracted by addition of a concentration of prostaglandin $F_{2 \alpha}(2-5 \mu \mathrm{M})$ sufficient to induce approximately $80 \%$ maximal contraction as previously determined. Stable contraction could be attained by prostaglandin $F_{2 \alpha}$ treatment over a sustained period. Tachyphylaxis was not observed. After stable contraction had been achieved, cumulative dopamine dose-response curves were obtained. For some strips, relaxation induced by dopamine in the first (exposure to dopamine) series of experiments was smaller than that achieved in the second to the fifth (exposure to dopamine) series, as has been previously described (3). For this reason, we used the second series of dose-response curves as controls. The ED50 concentrations were determined by probit analysis of dose-response curves.

Dopamine receptor subtype identification. In the experiments in which dopamine response antagonists were used (the third to fifth series), each antagonist, as well as $\alpha$ - and $\beta$-adrenergic and serotonergic blockers, were added to the medium $20 \mathrm{~min}$ before application of prostaglandin $\mathrm{F}_{2 \alpha}$. The $\alpha$-, $\beta$-, and serotonergic antagonists were added to eliminate the effects of dopamine and dopamine antagonists that operate through these receptors. Three dopamine antagonists were used: cis-flupenthixol $\left(10^{-8}\right.$, $\left.10^{-7}, 10^{-6} \mathrm{M}\right)$, metoclopramide $\left(10^{-7}, 10^{-6}, 10^{-5} \mathrm{M}\right)$, and sulpiride $\left(10^{-6}, 10^{-5} \mathrm{M}\right)$. Cis-flupenthixol is used as a $\mathrm{DA}_{1}$ receptor antagonist $(11,12)$. Metoclopramide and sulpiride are $\mathrm{DA}_{2}$ recep-

Table 1. Mean values ( $\pm S E M$ ) of cross-sectional areas, and contractions induced by $30 \mathrm{mM} \mathrm{KCl}$ per cross-sectional area, of pulmonary artery strips isolated from rabbits of different ages

\begin{tabular}{cccccc}
\hline $\begin{array}{c}\text { Age } \\
(\text { days })\end{array}$ & $n^{*}$ & $\begin{array}{c}\text { Body wt } \\
(\mathrm{g})\end{array}$ & $\begin{array}{c}\text { Cross-sectional } \\
\text { area }\left(\mathrm{mm}^{2}\right)\end{array}$ & $\begin{array}{c}\mathrm{RT} \dagger \\
(\mathrm{g})\end{array}$ & $\begin{array}{c}\text { Contraction/area } \\
\left(\mathrm{mg} / \mathrm{mm}^{2}\right)\end{array}$ \\
\hline 2 & 5 & $58.2 \pm 3.8$ & $0.584 \pm 0.062$ & 1.0 & $186.2 \pm 41.1$ \\
7 & 4 & $94.8 \pm 9.7 \S$ & $0.577 \pm 0.079$ & 1.0 & $281.3 \pm 69.2$ \\
14 & 8 & $235.6 \pm 17.0 \S$ & $0.579 \pm 0.057$ & 1.0 & $592.6 \pm 71.1$ \\
30 & 7 & $371.9 \pm 44.5 \S$ & $0.693 \pm 0.069$ & 1.0 & $928.7 \pm 144.3$ \\
90 & 5 & $2.840 \pm 120 \S$ & $1.162 \pm 0.248 \S$ & 1.6 & $1265 \pm 491.4 \S$ \\
\hline
\end{tabular}

* Number of strips.

$\dagger$ Resting tension.

$\ddagger \mathrm{KCl}(30 \mathrm{mM}$ )-induced contraction/cross-sectional area.

$\S$ Significantly different from 2 -day-old values, $p<0.05$. tor antagonists. Metoclopramide is also a $\mathrm{DA}_{1}$ receptor antagonist, although a relatively weak one (11). The concentrations of dopamine antagonists were selected on the basis of previously reported $\mathrm{pA}_{2}$ values $(3,13)$. Each strip was treated with one antagonist only. The concentrations of dopamine antagonists were increased. The order of the antagonist concentration was not randomized inasmuch as the prolonged effect from higher concentrations may have influenced the results seen with lower concentrations. Results were plotted according to the method of Arunlakshana and Shild (14) and the $\mathrm{pA}_{2}$ value was calculated for each experiment.

After obtaining the dose-response curves, the strips were washed at least five times. At the end of the experiments, the strips were treated with papaverine $\left(10^{-4} \mathrm{M}\right)$ to induce maximum relaxation. This relaxation was taken as $100 \%$ for relaxant responses.

Statistics. The results are expressed as mean values \pm SEM. One-way analysis of the variance was used to determine if a given parameter changed with age. If a statistically significant change was noted, the Scheffe F test was used to identify specific intergroup differences. Student's $t$ test or analysis of variance was used to test for statistical significance between paired or unpaired data at a given age. For all statistical tests, a $p$ value of 0.05 or less was regarded as a significant difference.

Drugs. Drugs used were dopamine $\mathrm{HCl}, d l$-propranolol $\mathrm{HCl}$, yohimbin $\mathrm{HCl}$, papaverine $\mathrm{HCl}$ (Nakarai, Kyoto, Japan), and sulpiride (Sigma Chemical Co., St. Louis, MO). Prazosin $\mathrm{HCl}$ was from Pfizer-Taito, Tokyo, Japan; methysergide from SANDOZ, Basel, Switzerland; prostaglandin $F_{2 \alpha}$ from Upjohn, Tokyo, Japan; cis-flupenthixol from Takeda, Osaka, Japan; and metoclopramide from Fujisawa, Osaka, Japan. Other chemicals used were of reagent grade.

\section{RESULTS}

Age-related changes in response to dopamine. In helical strips of pulmonary arteries isolated from 2- and 7-day-old rabbits which were partially precontracted with prostaglandin $F_{2 \alpha}$ the responses to dopamine $\left(10^{-9}\right.$ to $\left.10^{-4} \mathrm{M}\right)$ markedly differed from those in the other groups. In these age groups, the addition of dopamine $\left(10^{-9}\right.$ to $\left.10^{-5} \mathrm{M}\right)$ did not induce concentration-dependent relaxation but instead, at a high concentration $\left(10^{-3} \mathrm{M}\right)$, induced contraction. Furthermore, dopamine-induced relaxation in the infant rabbits could not be realized by increasing the concentration of prazosin. In precontracted strips isolated from 14-, 30-, and 90-day-old rabbits, however, the cumulative application of dopamine, in the presence of $\alpha$-and $\beta$-adrenergic and serotonergic blockers, induced a concentration-dependent relaxation (Fig. 1).

Mean values for the apparent dopamine ED50 concentrations in the arteries of 14-, 30-, and 90-day-old animals were $4.94 \pm$ $0.40 \mu \mathrm{M}$ (the number of arterial segments, $n=25$ ), $2.02 \pm 0.30$ $\mu \mathrm{M}(n=30)$, and $0.113 \pm 0.028 \mu \mathrm{M}(n=30)$, respectively, whereas the maximum relaxation induced in each group was $20.0 \pm 4.5 \%, 30.5 \pm 6.7 \%$, and $41.8 \pm 9.6 \%$, with papaverineinduced relaxation being taken as $100 \%$.

Dopamine receptor subtype identification. Cis-flupenthixol showed significant competitive inhibition of dopamine-induced relaxation in strips isolated from 14-, 30-, and 90-day-old rabbits (Fig. 2). Table 2 shows the mean values for the apparent dopamine ED50 concentrations in the presence of cis-flupenthixol $\left(10^{-7}, 10^{-6}\right.$, and $\left.10^{-5} \mathrm{M}\right)$. The $\mathrm{pA}_{2}$ values for cis-flupenthixol in pulmonary arteries of 14-, 30-, and 90-day-old rabbits were as follows: $6.90 \pm 0.30(n=8), 6.85 \pm 0.55(n=7)$, and $6.90 \pm$ $0.33(n=12)$, respectively. These values are similar to those previously reported for rabbit splenic arteries (13). The analysis could not be conducted in strips from 2- and 7-day-old rabbits due to the absence of dopamine-induced relaxation.

Metoclopramide partially antagonized the relaxant effect of dopamine in strips from 90 -day-old rabbits. It did not, however, 

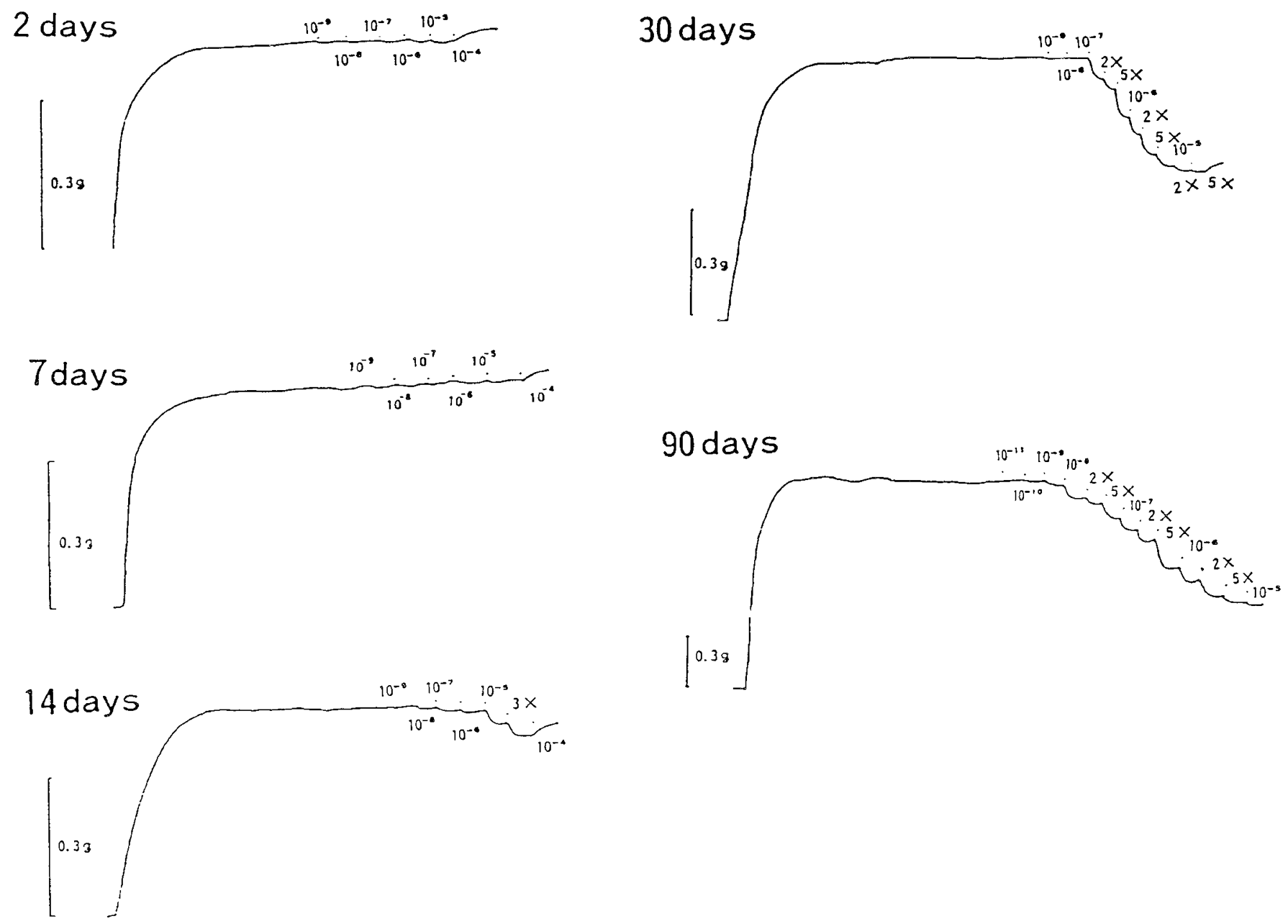

Fig. 1. Representative patterns of dopamine-induced relaxation. In strips from 2-and 7-day-old rabbits, the addition of dopamine did not induce relaxation. In strips from 14-, 30-, and 90-day-old rabbits the application of dopamine induced a concentration-dependent relaxation.

inhibit dopamine-induced relaxation in strips from 14- and 30day-old rabbits (Fig. 3). Table 3 shows the mean values for the apparent dopamine ED50 concentrations in the presence of metoclopramide $\left(10^{-7}, 10^{-6}, 10^{-5} \mathrm{M}\right)$. This analysis could not be performed in strips from 2-and 7-day-old rabbits.

Sulpiride $\left(10^{-6}, 10^{-5} \mathrm{M}\right)$ did not influence the dopamineinduced relaxation in strips from 14-, 30-, or 90-day-old rabbits.

\section{DISCUSSION}

This in vitro study demonstrated that the pulmonary vasculature, isolated from rabbits 14-, 30-, and 90-days old, dilated in response to dopamine, whereas vessels from younger rabbits did not. The experimental procedure facilitated the investigation of dopamine receptor-mediated relaxation of the pulmonary artery without any effects mediated through other receptors. That is, the dopamine receptor that mediates relaxation was detected in adults but not in younger animals. This study supplements observations made by several investigators using a variety of animals in vitro who have reported that the response to dopamine changed during development, and that there is remarkable heterogeneity in vascular smooth muscle reactivity in different vascular beds of various species (15-20).

Gootman et al. (15) examined the cardiovascular effects of a single bolus injection of dopamine during postnatal development. Renal vasoconstriction was noted in young swine, whereas vasodilatation occurred in older animals after $\alpha$ - and $\beta$-adrenergic receptor blockade. Bucky et al. (16) observed renal vasoconstriction in swine younger than 1 month even after a single, low, intravenous dose of dopamine unless $\alpha$-adrenergic receptors were blocked by phentolamine. In addition, they evaluated the regional circulatory effects of dopamine infused into developing swine and suggested that the developmental time course of dopamine receptors differed from the particular regional circulation (17).

In pentobarbital-anesthetized open chest puppies, 3-65 days of age, renal blood flow increased without concomitant decreases in renal vascular resistance (18). Pelayo et al (19), using anesthetized puppies, observed increased renal blood flow during intrarenal dopamine infusion only in older puppies $(49.8 \pm 2.5$ days of age), both with and without combined $\alpha$ - and $\beta$-blockade, and age-dependent increases in the glomerular filtration rate and renal sodium handling. In unanesthetized newborn lambs (mean age $7 \pm 2$ day) dopamine did not selectively vasodilate the vascular bed of any organ tested despite an increase in cardiac output (20). These findings support the concept that dopamine receptors are immature at birth and show age-dependent changes in their responses to dopamine.

This is further illustrated by observations that isolated aortae and arteries from rabbits at different stages of development respond differently to vasoactive agents. The $\beta$-adrenergic mechanism has been shown to be not fully developed in newborn rabbits. Strips of pulmonary arteries and aortae from 1- to 2day-old rabbits produced only small relaxations in response to isoproterenol but reached a maximal level by 1 month of age (4). In contrast, relaxation in response to sodium nitrite or papaverine remained constant at all ages. The changes in the effectiveness of isoproterenol with maturation may be due to a 

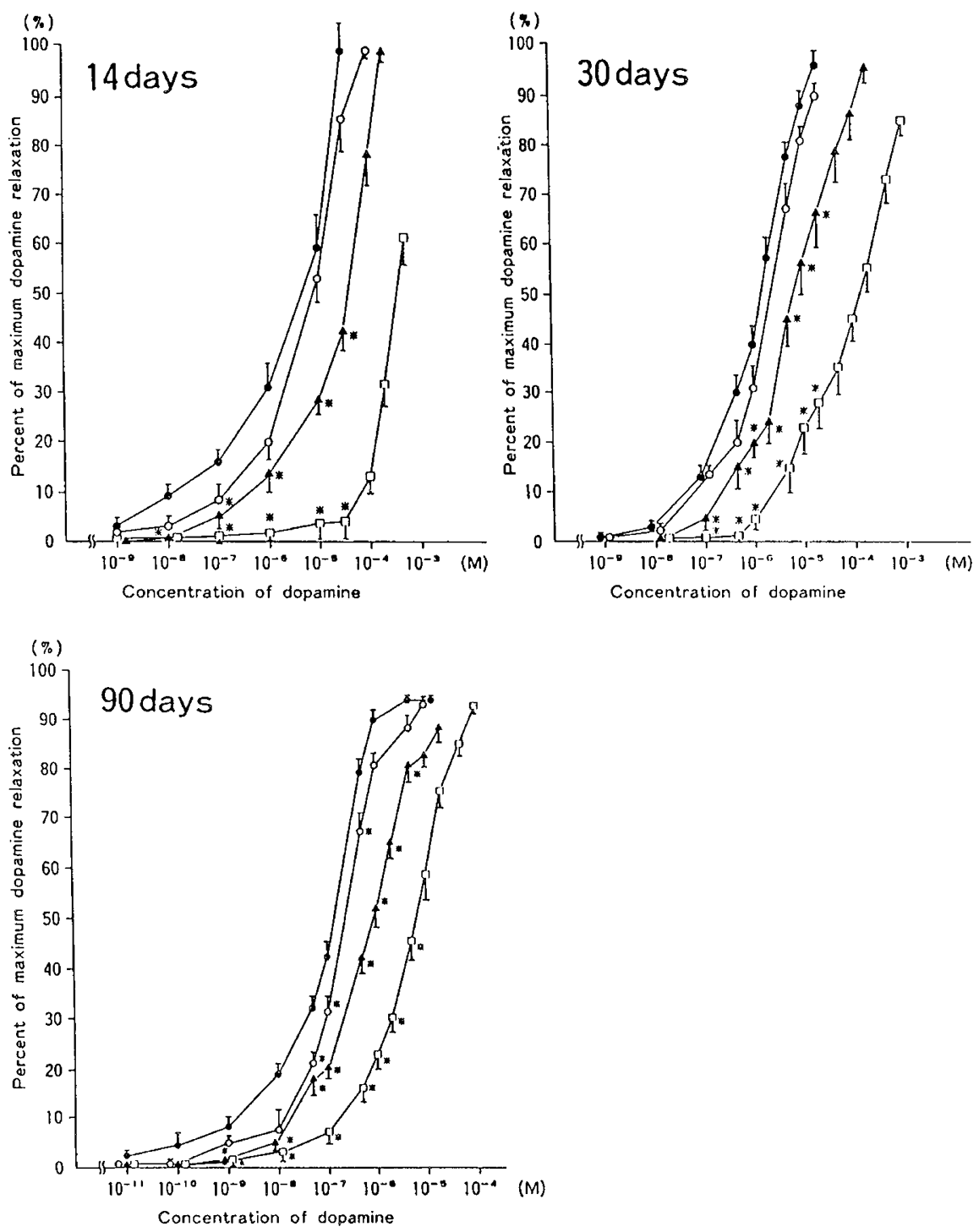

Fig. 2. Effect of cis-flupenthixol on dopamine dose-response curves in strips from different age groups, 14 days $(n=8)$, 30 days ( $n=7)$, and 90 days $(n=12)$. Closed circles, dopamine alone; open circles, with cis-flupenthixol $10^{-7} \mathrm{M}$; closed triangles, with cis-flupenthixol $10^{-6} \mathrm{M}$; open squares, with cis-flupenthixol $10^{-5} \mathrm{M} . *$ Values significantly different from those obtained for dopamine-induced relaxation without cis-flupenthixol.

Table 2. Effect of cis-flupenthixol on ED50 concentration of dopamine ( $\mu M$ mean $\pm S E M)^{*}$

\begin{tabular}{cccc}
\hline $\begin{array}{c}\text { Concentration of } \\
\text { cis-flupenthixol }(\mathrm{M})\end{array}$ & $\begin{array}{c}14 \text { days } \\
(n=8)\end{array}$ & $\begin{array}{c}30 \text { days } \\
(n=7)\end{array}$ & $\begin{array}{c}90 \text { days } \\
(n=12)\end{array}$ \\
\hline Control & $4.97 \pm 0.97$ & $2.02 \pm 0.64$ & $0.109 \pm 0.034$ \\
$1.0 \times 10^{-7}$ & $8.87 \pm 2.27$ & $2.84 \pm 0.42$ & $0.277 \pm 0.034 \ddagger$ \\
$1.0 \times 10^{-6}$ & $44.73 \pm 7.11 \ddagger$ & $14.78 \pm 4.97 \ddagger$ & $1.184 \pm 0.137 \ddagger$ \\
$1.0 \times 10^{-5}$ & $362.75 \pm 30.18 \ddagger$ & $167.19 \pm 49.16 \ddagger$ & $8.077 \pm 1.208 \ddagger$ \\
\hline
\end{tabular}

* Effect of cis-flupenthixol on ED50 concentration of dopamine could not be determined in the strips from 2-day-old group ( $n=8)$ and 7-dayold group $(n=7)$.

$\dagger$ Number of strips.

$¥$ Significantly different from control values, $p<0.05$.

decreasing effectiveness of cAMP in producing relaxation (21) or to a decrease in the number of receptors.

In most studies, there was an increase in the maximal response to norepinephrine in the first few weeks of life when the results were corrected for the contractile ability of the tissue. Hayashi and Toda $(22,23)$ found that the $\alpha$-adrenergic mechanism was immature in the aortae of neonatal rabbits, but developed during the first 30 postnatal days, whereas the response in rabbit basilar arteries did not alter with age. However, the effects of histamine relative to contractions induced by $50 \mathrm{mM} \mathrm{KCl}$ were not different in basilar arteries and aortae of rabbits of different ages. These findings, comparing different agonists and different rabbit arteries, indicate that age-dependent changes are associated with alterations in either the number or the sensitivity of receptors, rather than an alteration in contractility of the arterial smooth muscles.

Change in sensitivity during development. There is considerable disagreement concerning the sensitivity of arterial smooth muscles to various vasoactive agents during animal development (6). Some investigators have noted no changes in ED50 concen- 

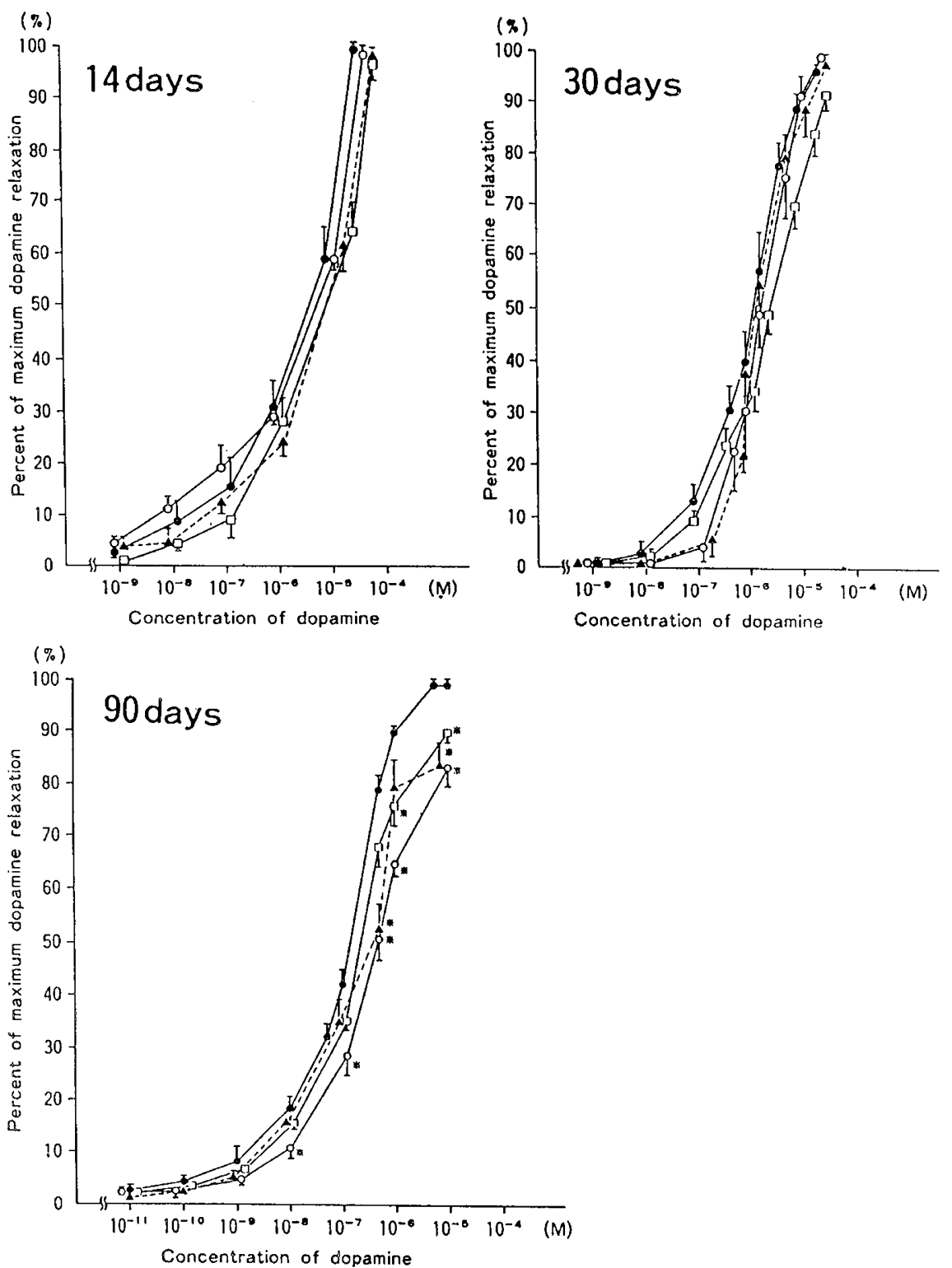

Fig. 3. Effect of metoclopramide on dopamine dose-response curves in strips from different age groups, 14 days $(n=6), 30$ days $(n=5)$, and 90 days $(n=12)$. Closed circles, dopamine alone; open circles, with metoclopramide $10^{-7} \mathrm{M}$, closed triangles, with metoclopramide $10^{-6} \mathrm{M}$; open squares, with metoclopramide $10^{-5} \mathrm{M}$. *Values significantly different from those obtained for dopamine-induced relaxation without metoclopramide.

Table 3. Effect of metoclopramide on ED50 concentration of dopamine ( $\mu M$ mean $\pm S E M)^{*}$

\begin{tabular}{cccc}
\hline $\begin{array}{c}\text { Concentration of } \\
\text { metoclopramide }(\mathrm{M})\end{array}$ & $\begin{array}{c}14 \text { days } \\
(n=6)\end{array}$ & $\begin{array}{c}30 \text { days } \\
(n=5)\end{array}$ & $\begin{array}{c}90 \text { days } \\
(n=12)\end{array}$ \\
\hline Control & $4.94 \pm 0.40$ & $2.02 \pm 0.30$ & $0.140 \pm 0.029$ \\
$1.0 \times 10^{-7}$ & $4.75 \pm 0.25$ & $2.03 \pm 0.83$ & $0.910 \pm 0.286 \ddagger$ \\
$1.0 \times 10^{-6}$ & $5.37 \pm 1.19$ & $1.82 \pm 0.28$ & $0.322 \pm 0.063 \ddagger$ \\
$1.0 \times 10^{-5}$ & $4.95 \pm 1.32$ & $2.49 \pm 0.44$ & $0.207 \pm 0.033$ \\
\hline
\end{tabular}

* Effect of metoclopramide on ED50 concentration of dopamine could not be determined in the strips from 2-day-old group $(n=8)$ and 7-dayld group $(n=7)$.

$\dagger$ Number of strips.

$\ddagger$ Significantly different from control values, $p<0.05$.

trations [noradrenaline in the sheep ear artery (24), guinea pig and rabbit renal arteries (25), rat portal vein (26), and rabbit basilar artery (27)], whereas others have observed decreases in ED50 concentrations [noradrenaline in the dog aorta (28) and sheep carotid artery (29)].
In our study, an age-dependent decrease in dopamine ED50 concentration was observed in pulmonary arteries isolated from rabbits aged 14-90 days. The dopamine-induced relaxation in infant rabbit arteries was not potentiated by increasing concentrations of prazosin, suggesting that the decreased sensitivity to dopamine in younger rabbits was not due to a counteractive effect on $\alpha$-receptors. The reason for the decrease in dopamine ED50 concentration with increasing age is unclear, although an increase in the number of receptors and/or increased dopamine affinity may be involved. No change was reported in the number of dopamine receptors in partially purified renal tubular membranes of puppies and adult dogs (30), whereas in renal arteries of the aged rabbits and the striatum of the aged rats a decrease in the number was noted $(31,32)$. The number of dopamine receptors in the pulmonary artery has yet to be measured by radioligand binding.

Dopamine receptor subtype identification. In our study, cisflupenthixol, the most potent $\mathrm{DA}_{1}$ antagonist in arterial strips $(3,31,32)$, significantly inhibited dopamine-induced relaxation in strips isolated from rabbits 14,30 , and 90 days old. $\mathrm{PA}_{2}$ values were similar in all three groups. Metoclopramide and sulpiride 
are potent $\mathrm{DA}_{2}$ receptor antagonists; the former was also a relatively weak $\mathrm{DA}_{1}$ receptor antagonist (31). In our study, sulpiride was inactive in strips from 14-, 30-, and 90-day-old rabbits, whereas metoclopramide was only partially active in strips from adults. Thus, $\mathrm{DA}_{1}$ seems to be the dopamine receptor present in the pulmonary artery throughout postnatal development.

In conclusion, pulmonary vasculature dilates in response to dopamine only in rabbits of the 14-, 30-, and 90-day-old group whereas in younger rabbits this response is absent. The ED50 concentration of dopamine decreased significantly during development from 14 to 90 days old. These findings suggest that the dopamine receptors in rabbit pulmonary arteries are immature at birth but mature with development. Furthermore, the dopamine receptor in the pulmonary artery strips isolated from 14-, 30 -, and 90-day-old rabbits seems to be of the $\mathrm{DA}_{1}$ type.

Acknowledgments. The authors express our gratitude to Dr. M. Kusunoki, Second Department of Surgery, Hyogo College of Medicine for his critical advice.

\section{REFERENCES}

1. Goldberg LI, Kohli JD 1979 Peripheral pre- and post-synaptic dopamine receptors: are they different from dopamine receptors in the central nervous system? Comm Psychopharmacol 3:447-456

2. Goldberg LI, Kohli JD 1983 Peripheral dopamine receptors: a classification based on potency series and specific antagonism. Trends Pharmacol Sci 4:64-66

3. Hoshino Y, Obara H, Iwai S 1986 Relaxant effect of dopamine on isolated rabbit pulmonary artery. Life Sci 39:2525-2531

4. Park MK, Diehl AM, Sunderson JM 1976 Maturation of beta-adrenergic receptor activity of rabbit aorta and pulmonary artery. Life Sci 19:321-328

5. Park MK, Sheridan PH 1979 Alpha- and beta-adrenergic mechanisms in the aorta of newborn rabbits and guinea-pigs. Gen Pharmacol 10:257-261

6. Duckles SP, Banner W Jr 1984 Changes in vascular smooth muscle reactivity during development. Annu Rev Pharmacol Toxicol 24:65-83

7. Toda N, Okamura T, Miyazaki M 1986 Age-dependent changes in the response of isolated beagle coronary arteries to transmural electrical stimmulation and catecholamines. J Pharmacol Exp Ther 238:319-326

8. Seidal CL, Michael BR, Freedmann J, Burdick B, Miller T 1987 Maturational changes in the pharmacological characteristics and actomyosin content of canine arterial and venous tissue. Pediatr Res 21:152-158

9. Doxey JC, Smith CFC, Walker JM 1977 Selectivity of blocking agents for preand postsynaptic alpha-adrenoceptors. Br J Pharmac 60:91-96

10. Kusunoki M, Taniyama K, Tanaka C 1985 Dopamine regulation of $\left[{ }^{3} \mathrm{H}\right]$ acetylcholine release from guinea-pig stomach. J Pharmacol Exp Ther 234:713-717
11. Cavero I, Massingham R, Lefevre-Borg F 1982 Peripheral dopamine receptors potential targets for a new class of antihypertensive agents. Part 1: subclassification and functional description. Life Sci 31:939-948

12. Brodde OE 1982 Vascular dopamine receptors: demonstration and characterization by in vitro studies. Life Sci 31:289-306

13. Hilditch A, Drew GM 1981 Characteristics of the dopamine receptors in the rabbit isolated splenic artery. Eur J Pharmacol 72:287-296

14. Arunlakshana O, Schild HO 1959 Some quantitative uses of drug antagonists. Br J Pharmacol 14:48-57

15. Gootman N, Bucky BJ, Gootman PM, Nagelberg JS 1982 Age-related effects of single injections of dopamine on cardiovascular function in developing swine. Dev Pharmacol Ther 4:139-150

16. Bucky NM, Brazeau P, Fraiser ID 1983 Cardiovascular effects of dopamine on developing swine. Biol Neonate 43:50-60

17. Gootman N, Buchy BJ, Gootman PM, Griswold PG, Mele JD, Nudel DB 1983 Maturation-related difference in regional circulatory effects of dopamine infusion in swine. Dev Pharmacol Ther 65:9-22

18. Driscoll DJ, Gillette PC, Lewis RM, Hartley CJ, Schwarz A 1979 Comparative hemodynamic effects of isoproterenol, dopamine, and dobutamine in the newborn dog. Pediatr Res 13:1006-1009

19. Pelayo JC, Fildes RD, Jose PA 1984 Age-dependent renal effects of intrarenal dopamine infusion. Am J Physiol 247:R212-R216

20. Feltes TF, Hansen TN, Martin CG, Leblanc AL, Smith S, Giesler ME 1987 The effects of dopamine infusion on regional blood flow in newborn lambs. Pediatr Res 21:131-136

21. Cohen ML, Berkowitz BA 1974 Age-related changes in vascular responsiveness to cyclic nucleotides and contractile agents. J Pharmacol Exper Ther 191:147-155

22. Hayashi S, Toda N 1978 Age-related changes in the response of rabbit isolated aortae to vasoactive agents. Br J Pharmacol 64:229-237

23. Toda N, Hayashi S 1979 Age-dependent alteration in the response of isolated rabbit basilar arteries to vasoactive agents. J Pharmacol Exper Ther 211:716721

24. Wyse DG, Van Petten GR, Harris WH 1977 Responses to electrical stimulation, noradrenaline, serotonin and vasopressin in the isolated ear artery of the developing lamb and ewe. Can J Physiol Pharmacol 55:1001-1006

25. Gallen DD, Cowen T, Griffith SG, Haven AJ, Burnstock G 1982 Functional and non-functional nerve-smooth muscle transmission in the renal arteries of the newborn and adult rabbit and guinea pig. Blood Vessels 19:237-246

26. Ljung B, Stage D 1975 Postnatal ontogenetic development of neurogenic and myogenic control in the rat portal vein. Acta Physiol Scand 94:112-127

27. Toda N, Hayashi S 1979 Age-dependent alteration in the response of isolated rabbit basilar arteries to vasoactive agents. J Pharmacol Exper Ther 211:716721

28. Gray SD 1977 Reactivity of neonatal canine aortic strips. Biol Neonate 31:10 14

29. Gray SD 1976 Effect of angiotensin on neonatal lamb carotid arteries. Experientia 32:350-351

30. Felder RA, Blecher M, Schoelkopf L, Calcagno L, Jose PA 1983 Renal dopamine receptors during maturation. Pediatr Res 17:369(abstr)

31. Collier WL, Iacopino L, Amenta F 1984 Changes of $\left[{ }^{3} \mathrm{H}\right]$ spiroperidol binding in the renal artery of aged rabbits. Mech Ageing Dev 28:41-45

32. Misra CH, Shelat HS, Smith RC 1980 Effect of age on adrenergic and dopaminergic receptor binding in rat brain. Life Sci 27:521-526 